\title{
ANALYSIS OF HEAVY METAL CONTENT OF PB IN BALLAST WATER TANK OF COMMERCIAL VESSELS IN PORT OF TANJUNG EMAS SEMARANG, CENTRAL JAVA PROVINCE
}

\author{
Agus Tjahjono $^{1 *}$, Azis Nur Bambang ${ }^{2}$, Sutrisno Anggoro² \\ 1 Post Graduate Student of Environmental Science, School of Post Graduate Studies, Diponegoro University, \\ Semarang, Central Java, 50241, Indonesia \\ 2 Department of Environmental Science, School of Post Graduate Studies, Diponegoro University, Semarang, \\ Central Java, 50241, Indonesia, e-mail: azis_undip2013@yahoo.com, sutrisno.anggoro@yahoo.co.id \\ * Corresponding Author's e-mail: a_agus_tjahjono70@yahoo.co.id
}

Received: 2016.12.06 Accepted: 2017.01.06 Published: 2017.03.01

\begin{abstract}
Heavy metal pollution in the port area had affected aquatic organisms. The research about the heavy metal content of ballast water of commercial vessels, both passenger or cargo vessels, berthing in Port of Tanjung Emas Semarang (PTES), has been conducted by using a method of AAS (Atomic Absorption Spectroscopy). Sample was gathered from vessels berthed in PTES, dated on December $18^{\text {th }} 2014$ to October $21^{\text {st }} 2015$. The results of the research show that the mean content of $\mathrm{Pb}$ in ballast water tank is $0.37192 \mathrm{mg} \cdot \mathrm{l}^{-1}$. Based on the Decree of Minister of Environment number $51 / 2004$, heavy metal content of $\mathrm{Pb}$ in ballast water tank has exceeded the quality standards of port waters.
\end{abstract}

Keywords: commercial vessels, ballast water tank, heavy metal content of $\mathrm{Pb}$

\section{INTRODUCTION}

Heavy metal pollution from industrial and domestic sources can affect coastal waters and heavy metals in waters positively correlated to the organic matter in the local waters [Srikanth et al., 2014; Maslukah, 2013]. Activities in the port basin were a source of heavy metal pollution [Kara et al., 2015]. Heavy metals from waste fuels have led to the results of the fisherman activities of $\mathrm{Pb}$ contamination in scallop shells, Amusium pleuronectes [Azhar et al., 2012]. Chromium in the waters has also caused blood clams, Anadra granosa has exceeded the threshold [Suprapti 2008].

The impact of heavy metal pollution in port waters can cause an increase in metal content in the aquatic organisms. The concentration of $\mathrm{Pb}$ in red fish (Lutjanus erythropterus) in the port of Pare Pare has exceeded the threshold [Us- man et al., 2013], what caused contamination of the waters of the port with $\mathrm{Pb}$ and $\mathrm{Zn}$ [Wahab \& Mutmainah, 2005].

Semarang estuary water is not deep and muddy in the bottom, dirty and has high solid suspense. The pollution comes from household waste originated from two main canals. The heavy metal content of $\mathrm{Pb}$ on the sediments of Semarang Port pond is higher than the estuary water in the canals of Banjir Kanal Timur and Banjir Kanal Barat. The concentration of $\mathrm{Zn}$ in the sediments is about 84.14-131.74 $\mathrm{mg} \cdot \mathrm{kg}^{-1}$, with the average of $97.11 \mathrm{mg} \cdot \mathrm{kg}^{-1}$ [Hartoko, 2013; Rositasari, 2013]. Heavy metals in coastal waters of north Java and east Sumatera island are increased [Arifin et al., 2012]. This study aims to determine heavy metal content of $\mathrm{Pb}$, and DWT (Dead Weight Ton) of the commercial vessels in Port of Tanjung Emas Semarang (PTES). 


\section{STUDY AREA}

The Port of Tanjung Emas Semarang (PTES) is located in the north coast of Central Java Province, Indonesia $\left(6^{0} 53^{\prime} \mathrm{S}, 110^{\circ} 24^{\prime} \mathrm{E}\right)$. The port is situated in the narrow side of the coast, less than $10 \mathrm{~km}$ in width. It gets wider in the eastern side, maximum speed of general streams is $0.31 \mathrm{knot}$ with the direction of $324^{\circ}$ in the afternoons, when the water level falls to the lowest tidal, and in the late afternoon, for about 0.28 knot with the direction of $164^{\circ}$. The stream of both the lowest and highest tidal is weak. There is a hindered and weak stream in front of port entrance [Jawatan Hidro-Oceanografi, 1983].

\section{MATERIAL AND METHODS}

The sample was gathered from vessels berthed in PTES, dated on December $18^{\text {th }} 2014$ to October $21^{\text {st }} 2015$. In commercial vessels, the samples were collected twice on one ballast water tank with DWT more than 400 tons. Research in ballast water tank of commercial vessels is conducted by using purposive sampling that covers 6 wharfs, like Pusri fertiliser and oil, passenger, domestic, wheat, container and LPG wharfs.

The capacity of ballast water for each vessel berthing on port is calculated by using a formula of $36.5 \%$ of general cargo, $35 \%$ of solid cargo, $35 \%$ of liquid cargo, $30 \%$ of container, $33 \%$ of mixed cargo, and $33 \%$ mixed cargo, and $33 \%$ of Ro-Ro vessels from DWT [Butron et al., 2011].

The water sample in ballast tank is collected by using the method conducted by putting sounding meter in ballast water tank through sounding pipes. Portable pump and suction hoses are used to collect the water sample [Garret et al., 2011]. The portable pump is from Sanyo brand, model
P-WH137C, 220 V 50 Hz of voltage source, 125 $\mathrm{W}$ of output power, 30 liters/minute of maximum water capacity. The suction hose is $0.019 \mathrm{~m}$ in diameter and 10 meters in length. The end of suction hose is ended with a foot valve. The water sample of the ballast water in the surface of the tank can be collected by rising the end of suction hose, while the water sample from the bottom of the tank can be collected by lowering the end of the suction hose.

Sample of the ballast water, that is on the surface of the tank, can also be collected by opening manhole in the ballast tank of commercial vessels. Sample of water that is at the bottom of the tank, is collected by using a 10-liter bucket.

The water sample is filtered by using 40 $(0.42 \mu \mathrm{m})$ whatman filter paper and washed by using $\mathrm{HNO}_{3}$ concentrated to $\mathrm{pH}<2$. Then, it is placed in water sampler of 5 liter in volume. The water sample is then brought to the laboratory. The water $(100 \mathrm{ml})$ is mixed thoroughly and put in a beaker. Then, it is added by $5 \mathrm{ml}$ of citric acid and heater, $50 \mathrm{ml}$ of distilled water is added, and the mixture is put in $100 \mathrm{ml}$ of graduated flask [BSN, 2009].

The level of heavy metal $\mathrm{Pb}$ in the sample of ballast water of commercial vessel is determined by AAS (Atomic Absorption Spectroscopy) type Shimadzu AA-6300 by using flame-mixed of air acetylene.

\section{RESULTS AND DISCUSSION}

Heavy metal content of $\mathrm{Pb}$ in ballast water is about $0.003-1.59 \mathrm{mg} . \mathrm{l}^{-1}$. Metal content of $\mathrm{Pb}$ from ballast water tank in passenger vessels of $\mathrm{S}, \mathrm{B}$, and $\mathrm{L}$ are almost the same, i.e. about $0.03 \mathrm{mg} \cdot \mathrm{l}^{-1}$. Those passenger vessels are from Jakarta, Sampit and Pontianak ports and ballast water tank in those passenger vessels are merged, between star-

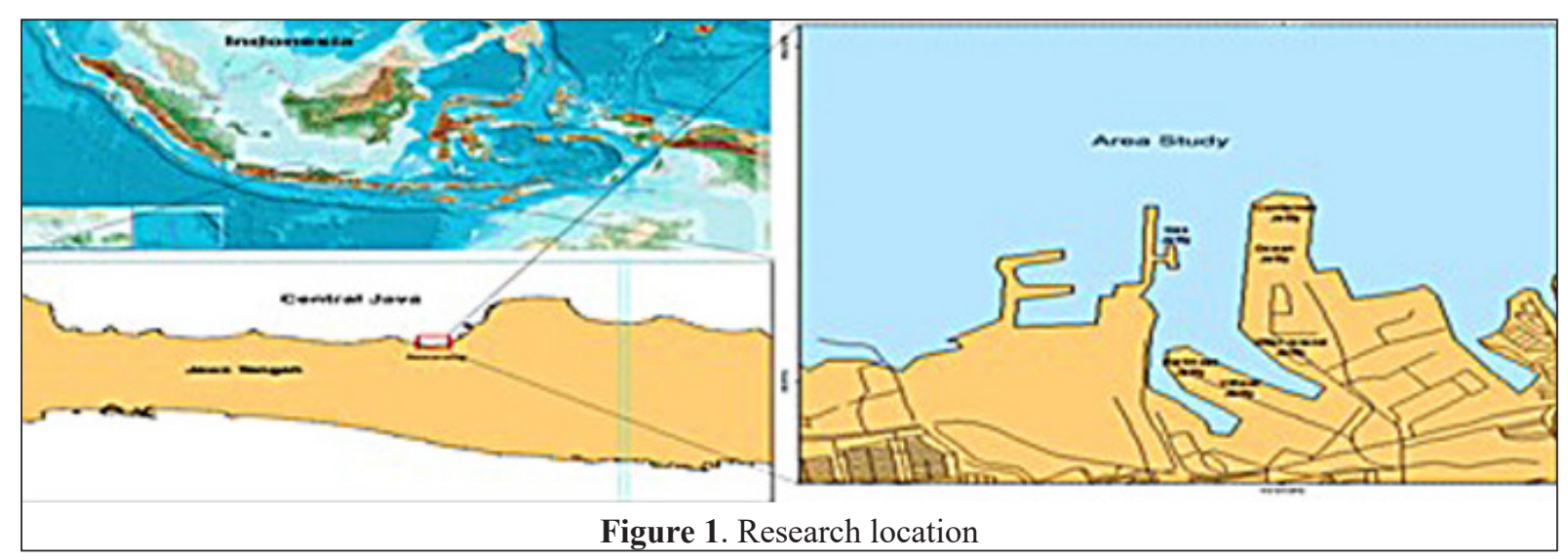


board and portside tanks. While the capacity of ballast water tank in $\mathrm{S}$ vessel is $74.4 \mathrm{~m}^{3}$ (the right side tank number 61), B and $\mathrm{L}$ is $213 \mathrm{~m}^{3}$ (the right and left side tank number 32).

Ballast water tanks in cargo vessels are separated between the right and left side. $\mathrm{C} 1$ vessel from Pontianak contains $\mathrm{Pb} 0.04 \mathrm{mg} \cdot \mathrm{l}^{-1}$. The vessels loading fertilizer from Palembang are Y, SB, MP, OK, PI and IZ. They berth on Pusri wharf that contains $\mathrm{Pb}$ from 0.005 to $0.63 \mathrm{mg} \cdot \mathrm{l}^{-1}$. MP is a fertilizer carrier with $\mathrm{Pb}$ content 14 times higher than the quality standard. The next sample of ballast water is from Banyuwangi. It is collected from number 4 left side tank of GW, an LPG carrier that berths on Pertamina wharf, $\mathrm{Pb}$ content is from 0.07 to $0.12 \mathrm{mg} \cdot 1^{-1}$. In container wharf, there are PA and SB vessels, from New Orleans and Singapore respectively, and $\mathrm{Pb}$ content are 0.04 to $0.12 \mathrm{mg} \cdot \mathrm{l}^{-1}$ respectively. TS XII vessel that berths on asphalt wharf has $\mathrm{Pb}$ content of 0.008 to $0.009 \mathrm{mg} \cdot 1^{-1}$. M and C 8 vessels from Jakarta and Dumai respectively has $\mathrm{Pb}$ content that fulfill the quality standards.

Vessel from Sorong, GD, with the capacity of 426 tons in its ballast water tank, has $\mathrm{Pb}$ content 0f 13.8 times higher than the quality standard. BC $\mathrm{S}$ that is from Singapore has the deadweight of 9,957 MT, the ballast tank capacity is 5,032 tons and $\mathrm{Pb}$ content is 13.6 times higher than the quality standard. GNA is an LPG carrier that berths on JMI (Jasa Marina Indah) dockyard, has the deadweight of 5,589 MT, from Jakarta and has capacity of ballast tank is $289 \mathrm{~m}^{3}$. It has $\mathrm{Pb}$ content of 11.6 times higher than the quality standard because the water surface in its ballast water tank is only 2 meter left. NG is a cargo vessel that has $\mathrm{Pb}$ content 14 times higher than the quality standard (Figure 2).

The passenger vessel of $\mathrm{S}$, that has dead weight of 1400 tons and berthed on December $19^{\text {th }} 2014$, has 11 of ballast water tank. They have a total ballast water capacity of 818 tons. The sample was collected from ballast water tank number 61, starboard and port side tank. The tanks are interconnected. Her ballast water capacity was 76.3 tons. The ballast water origin is from Jakarta dockyard waters, oil polluted waters. The passenger vessels of B, DWT of 1450 tons, was berthed on December $18^{\text {th }} 2015$. She has 11 ballast water tanks with the total capacity of 819.3 tons. The sample was collected from ballast water tank number 32 (port side and starboard tank). It has the capacity of 218 tons. Ballast water origin is from Pontianak.

The passenger vessel of L, with DWT of 1400 tons, was berthed on January $7^{\text {th }} 2015$. She also has 11 ballast water tanks with the total capacity of 819.3 tons. The sample was collected from Double Bottom Deep tank number 32 (port side and starboard tank). She has ballast water capacity of 218.6 tons, its ballast water from Pontianak. Ce 1 vessel that loads rice is also from the same waters.

The fertilizer carriers of J and SB are from the same port of origin, Palembang. The vessels have deadweight of 11,615 and 9,237.4 tons respectively. The sample of ballast water from each of the vessel was collected from ballast water tank number 4 (port side) and number 3 (starboard). While another fertilizer carrier, A, is from Jakarta.

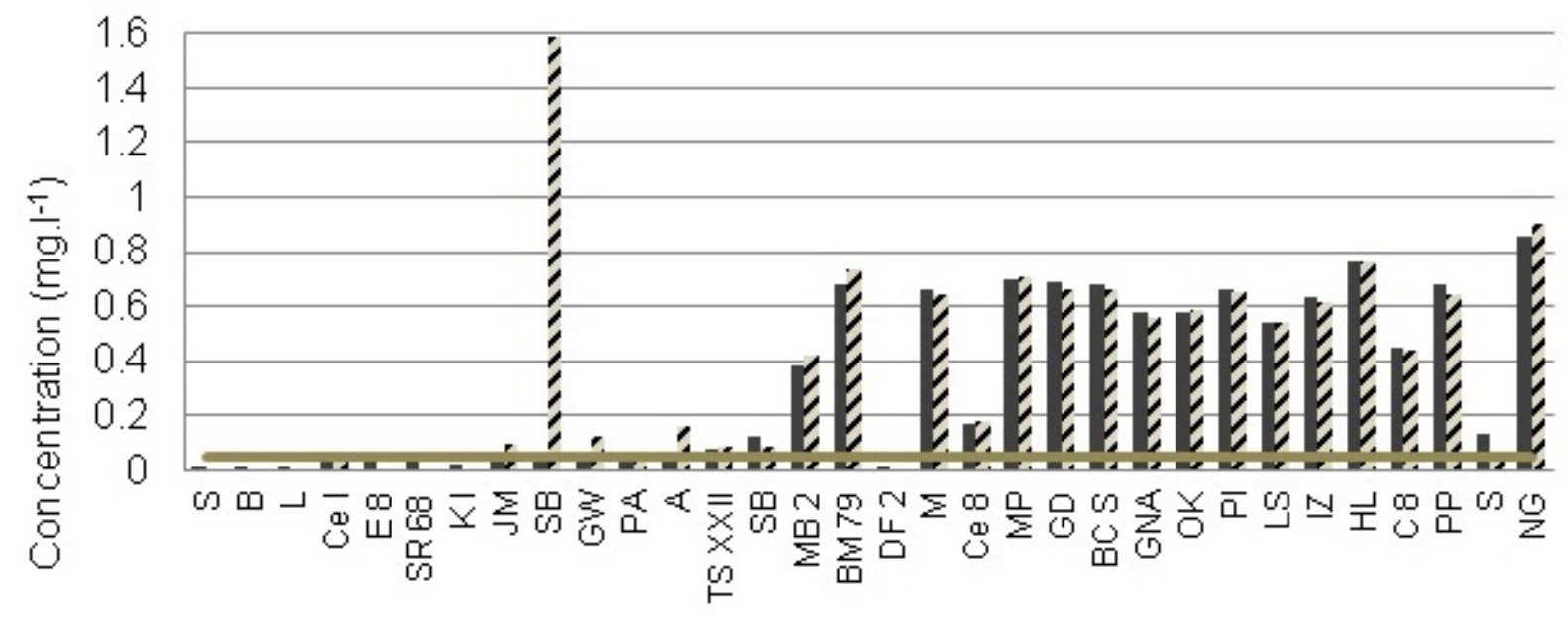

-First sampling

Figure 2. $\mathrm{Pb}$ concentration $\left[\mathrm{mg} \cdot \mathrm{l}^{-1}\right]$ in ballast water tank of commercial vessels 
The characteristics of heavy metal are specific gravity of $4 \mathrm{gr}^{\cdot} \mathrm{cm}^{-3}$ or more, atom number responds to specific biochemistry on living organism [Rhidowati, 2013; Palar, 2008]. The source of heavy metal pollutants are from natural and artificial sources. The natural source is from the coastal area (from rivers and coastal abrasion due to wave activity), metal released from volcanoes activity, and chemistry process. The artificial source is from industrial process of mining activity.

Lead solubility is low in waters so that the level of lead in water is relatively low. Both the content and toxicity of lead are influenced by hardness, $\mathrm{pH}$, alkalinity, and oxygen concentration. Lead toxicity is reduced by the increase of hardness and dissolved oxygen [Effendi, 2008]. It is categorized into IV-A group in periodic table of chemical elements, atom number of 82 with atom weight of 207.2, concentrated in deposit, such as metal ores. In battery industry, lead is used as a grid, compound of bismuth metal ( $\mathrm{Pb}-\mathrm{Bi})$ with ratio 93:7. $\mathrm{Pb}$ compound and $\mathrm{Cr}$, $\mathrm{Mo}$ and $\mathrm{Cl}$ are widely used as pigment chrome, lead silicate compound ( $\mathrm{Pb}$-silicate) used as one of ceramic polished materials, and used as refractory material [Rhidowati, 2013].

Heavy metal pollution in middle of Jakarta bay in June and September 2003 was dominated by $\mathrm{Zinc}$ metal in order of $\mathrm{Zn}>\mathrm{Cu}>\mathrm{Cd}$. Tanjung Priok port area becomes a place for vessels to dump their ballast water, industry and domestic wastes [Rochyatun \& Rozak, 2007] (Table 1). The sample of ballast water from Tanjung Priok port was collected from A, GNA, M and MB2 vessels (Table 2). The average of heavy metal of

Table 1 Comparison results of $\mathrm{Pb}$ concentration

\begin{tabular}{|l|c|l|}
\hline Vessels/Waters & $\begin{array}{c}\text { Concentration of } \\
\mathrm{Pb}\left(\mathrm{mg} \cdot \mathrm{l}^{-1}\right)\end{array}$ & \multicolumn{1}{|c|}{ References } \\
\hline Vessels in port & $0.003-1.59$ & Recent study \\
\hline Cisadane estuary & $<0.001-0.005$ & $\begin{array}{l}\text { Rochyatun et. al., } \\
2006\end{array}$ \\
\hline Jakarta bay & $0.001-0.003$ & $\begin{array}{l}\text { Lestari dan } \\
\text { Edward, 2004 }\end{array}$ \\
\hline Bangka waters & $0.001-0.026$ & Arifin, 2011 \\
\hline
\end{tabular}

Table 2 Comparison between of heavy metal of $\mathrm{Pb}$ in sediments in the bay of Jakarta and vessels from Jakarta

\begin{tabular}{|c|c|c|}
\hline \multirow{2}{*}{ Parameter } & \multicolumn{2}{|c|}{ Research location $\left(\mathrm{mg} \cdot \mathrm{I}^{-1}\right)$} \\
\cline { 2 - 3 } & $\begin{array}{c}\text { Middle of Jakarta } \\
\text { bay }\end{array}$ & Vessels from Jakarta \\
\hline $\mathrm{Pb}$ & $6.74-68.22$ & $0.07-0.66$ \\
\hline
\end{tabular}

$\mathrm{Pb}$ from vessels is about $0.37192 \mathrm{mg} \cdot \mathrm{l}^{-1}$, it has exceeded the quality standards of port waters at a value of $0.005 \mathrm{mg} \cdot \mathrm{l}^{-1}$.

\section{CONCLUSION}

1. The result of the study shows that the average $\mathrm{Pb}$ content of ballast water vessels is about $0.37192 \mathrm{mg} . \mathrm{l}^{-1}$. It happens because the vessels are quite old and influenced by sea water of origin port.

2. Heavy metal content in the ballast water of commercial vessels showed that heavy metals can be spread by commercial vessels. The more frequency vessels entry and more dead weight, more dangerous the ballast water discharged into the port waters. It will put the marine environment around the port in danger.

3. Commercial vessels before entering into the port waters should exchange ballast water in mid journey, ensure that the age of the water ballast in ballast tanks should not be more than 100 days, passenger vessels should fill fresh water into ballast tanks, and ensure that balast water is free of sediments.

\section{Acknowledgements}

The authors want to show his deepest gratitude to whose have helped in this research. They are Office of Harbour Master and Port Authorities of Tanjung Emas Semarang, the Ship's Officers who give permission to the technicians on board, and the staffs of Regional Health Laboratories Semarang in analyzing the sample.

\section{REFERENCES}

1. Butron A., Orive E. and Madariaga I. 2011. Potential risk of harmful algae transport by ballast waters: the case of Bilbao Harbor. Journal Marine Pollution Bulletin, 62, 747-757.

2. Hartoko A. 2013. Oceanographic Characters and Plankton Resources of Indonesia. Graha Ilmu, Yogyakarta, pp. 55-56.

3. Wahab A., Mutmainah W. 2005. Analisis kandungan logam berat timbal dan seng di sekitar perairan pelabuhan Parepare dengan metode adisi standar. Marina Chimica Acta, 6(2), 21-24.

4. Badan Standardisasi Nasional (BSN). 2009. Cara uji timbal dengan Spektrofometri Serapan Atom (SSA)-nyala, SNI 6989.8, pp. 1-15. 
5. Rochyatun E., dan Rozak A. 2007. Pemantauan kadar logam berat dalam sedimen di perairan Teluk Jakarta, Jurnal Makara Sains, 11(1), 28-36.

6. Azhar H., Widowati I., Suprijanto J. 2012. Studi kandungan logam berat $\mathrm{Pb}, \mathrm{Cu}, \mathrm{Cd}, \mathrm{Cr}$ pada kerang simping (Amusim pleuronectes), air dan sedimen di perairan Wedung, Demak serta analisis maximum tolerable intake pada manusia. Journal of Marine Research, 1(2), 35-44.

7. Effendi H. 2006. Telaah kualitas air bagi pengelolaan sumber daya dan lingkungan perairan. Penerbit Kanisius, Yogyakarta, pp. 64-66.

8. Palar H. 2008. Pencemaran dan toksilogi logam berat. Rineka Cipta, Jakarta, pp. 23-24.

9. International Maritime Organization (IMO). 2009. Ballast Water Management Convention 2004 Edition. International Maritime Organization, London, pp. 49-54.

10. Jawatan Hidro-Oseanografi. 1983. Informasi pelabuhan Indonesia. Jawatan Hidro-Oseanografi, Jakarta, pp. 16-19.

11. Srikanth K., Ahmad I., Rao J.V. 2014. Seasonal trend of potential toxic elements in seawater and sediments from Tuticorin coast. Water Air Soil Pollution, 225(2069) , 1-10.

12. Maslukah L. 2013. Hubungan antara konsentrasi logam berat $\mathrm{Pb}, \mathrm{Cd}, \mathrm{Cu}, \mathrm{Zn}$ dengan bahan organik dan ukuran butir dalam sedimen di estuari Banjir Kanal Barat, Semarang. Buletin Oseanografi Marina, 2, 55-62.

13. Lestari dan Edward. 2004. Dampak pencemaran logam berat terhadap kualitas air laut dan sumber daya perikanan (studi kasus kematian massal ikan-ikan di
Teluk Jakarta). Jurnal Makara Sains, 8(2), 52-58.

14. Kara M., Dumanoglu Y., Altiok H., Elbir T., Odabasi M., Bayram A. 2015. Spatial variation of trace elements in seawater and sediment samples in a heavily industrialized region. Environ Earth Sci, 73, 405-421.

15. Garret M.J., Wolny J.L., Williams B.J., Dirks M.D., Brame J.A. and Richardson R.W. 2011. Methods for sampling and analysis of marine microalgae in ship ballast tanks : a case study from Tampa Bay, Florida, USA. J. Algae, 26(2), 181-192.

16. Suprapti N.A. 2008. Kandungan chromium pada perairan, sedimen dan kerang darah (Anadara granosa) di wilayah pantai sekitar muara sungai Sayung desa Morosari kabupaten Demak, Jawa Tengah. BIOMA, 10(2), 36-40.

17. Rositasari R.L. 2013. Evaluasi Lingkungan Perairan Pesisir Semarang. Jurnal Ilmu dan Teknologi Kelautan Tropis, 5(1), 112-121.

18. Rhidowati S. 2013. Mengenal pencemaran logam. Graha Ilmu, Yogyakarta, pp. 1-2.

19. Usman S., Nafie N.L., Ramang M. 2013. Distribusi kuantitatif logam berat $\mathrm{Pb}$ dalam air, sedimen dan ikan merah (Lutjanus erythropterus) di sekitar perairan pelabuhan Parepare. Marina Chimica Acta, 14(2), 49-55.

20. Arifin Z., Puspitasari R., Miyazaki N. 2012. Heavy metal contamination in Indonesian coastal marine ecosystem: a historical perspective. Coastal Marine Science, 35(1), 227-233.

21. Arifin Z. 2011. Konsentrasi logam berat di air, sedimen dan biota di Teluk Kelabat, Pulau Bangka. Jurnal Ilmu dan Teknologi Kelautan Tropis, 3(1), 104-114. 